Supporting Information for:

\title{
Copolymerization of Ethylene and Vinyl Fluoride by (Phosphine-sulfonate)Pd(Me)(py) Catalysts
}

Wei Weng, Zhongliang Shen, and Richard F. Jordan*

Department of Chemistry, The University of Chicago, 5735 South Ellis Avenue, Chicago, Illinois, 60637

E-mail: rfjordan@uchicago.edu 


\section{Experimental Procedures}

General procedures. All experiments were performed using dry box or Schlenk techniques under a nitrogen atmosphere. Nitrogen was purified by passage through columns containing activated molecular sieves and Q-5 oxygen scavenger. $\mathrm{CH}_{2} \mathrm{Cl}_{2}$ and $\mathrm{CD}_{2} \mathrm{Cl}_{2}$ were distilled from $\mathrm{P}_{2} \mathrm{O}_{5}$. Hexane and toluene were purified by passage through columns of activated alumina and BASF R3-11 oxygen scavenger. Catalysts 1a and 1b were prepared as described previously. ${ }^{1}$ (TMEDA)PdMe 2 was prepared by a literature procedure. ${ }^{2}$ Ethylene (Polymer grade) was purchased from Matheson and used as received. Vinyl fluoride (VF) of $>98 \%$ purity was purchased from SynQuest Laboratories, Inc. and used as received.

NMR spectra of organometallic complexes were recorded at ambient temperature unless otherwise indicated. ${ }^{1} \mathrm{H}$ and ${ }^{13} \mathrm{C}$ chemical shifts are reported relative to $\mathrm{SiMe}_{4}$ and were determined by reference to the residual ${ }^{1} \mathrm{H}$ and ${ }^{13} \mathrm{C}$ solvent resonances. ${ }^{19} \mathrm{~F}\left\{{ }^{1} \mathrm{H}\right\}$ NMR spectra were referenced externally with trifluoroacetic acid in $\mathrm{CDCl}_{3}$ at $\delta$-78.5. Coupling constants are given in $\mathrm{Hz}$.

Polymer characterization. Gel permeation chromatography was performed with a Polymer Laboratories PL-GPC 220 instrument using 1,2,4-trichlorobenzene solvent (stabilized with $125 \mathrm{ppm} \mathrm{BHT)}$ at $150{ }^{\circ} \mathrm{C}$. A set of three PLgel $10 \mu \mathrm{m}$ Mixed-B LS columns was used. Samples were prepared at $160{ }^{\circ} \mathrm{C}$. Molecular weights were determined by GPC using narrow polystyrene standards and are corrected for linear polyethylene by universal calibration using the Mark-Houwink parameters of Rudin: $\mathrm{K}=1.75 \times 10^{-2} \mathrm{~cm}^{3} / \mathrm{g}$ and $\alpha=0.67$ for polystyrene and $\mathrm{K}$ $=5.90 \times 10^{-2} \mathrm{~cm}^{3} / \mathrm{g}$ and $\alpha=0.69$ for polyethylene. ${ }^{3}$

DSC measurements were performed on a TA Instruments DSC 2920 instrument. Samples (5 mg) were annealed by heating to $150{ }^{\circ} \mathrm{C}$ at $20{ }^{\circ} \mathrm{C} / \mathrm{min}$, cooled to $40{ }^{\circ} \mathrm{C}$ at $40{ }^{\circ} \mathrm{C} / \mathrm{min}$, and then analyzed while being heated to $150{ }^{\circ} \mathrm{C}$ at $20{ }^{\circ} \mathrm{C} / \mathrm{min}$.

${ }^{1} \mathrm{H}$ and ${ }^{19} \mathrm{~F}\left\{{ }^{1} \mathrm{H}\right\}$ NMR spectra for polymers were obtained as follows. A mixture of polymer (30-60 mg) and $\mathrm{CDCl}_{2} \mathrm{CDCl}_{2}(0.7 \mathrm{~g})$ in an NMR tube was heated to $120^{\circ} \mathrm{C}(\leq 15 \mathrm{~min})$ affording a homogeneous solution. The tube was inserted into a pre-heated NMR probe at $120^{\circ} \mathrm{C}$ and NMR spectra were obtained after a 5 min temperature equilibration period. ${ }^{13} \mathrm{C}\left\{{ }^{1} \mathrm{H}\right\} \mathrm{NMR}$ spectra were obtained from solutions of the copolymer $(80 \mathrm{mg})$ in 1,2-dichlorobenzene- $d_{4}(0.8 \mathrm{~g})$ at $110{ }^{\circ} \mathrm{C}$.

Ortho-(Diphenylphosphino)toluenesulfonic acid ([PO-H]H). A flask was charged with 
p-toluenesulfonic acid (2.10 g, $12.2 \mathrm{mmol}$, dehydrated) and THF (60 mL). The mixture was cooled to $0{ }^{\circ} \mathrm{C}$, stirred for $10 \mathrm{~min}$, and n-hexyllithium $(10.6 \mathrm{~mL}$ of a $2.3 \mathrm{M}$ solution in hexane, $24.4 \mathrm{mmol}$ ) was added dropwise over $3 \mathrm{~min}$. The mixture was warmed to $50{ }^{\circ} \mathrm{C}$ for $10 \mathrm{~min}$ and then cooled to $-78{ }^{\circ} \mathrm{C}$. A second flask was charged with THF $(60 \mathrm{~mL}), \mathrm{Ph}_{2} \mathrm{PCl}(2.25 \mathrm{~mL}, 12.2$ mmol) was added by syringe, and the solution was cooled to $-78{ }^{\circ} \mathrm{C}$. The dilithiated p-toluenesulfonic acid solution was cannula-transferred to the $\mathrm{Ph}_{2} \mathrm{PCl}$ solution to afford a pale yellow slurry, which was stirred at $-78^{\circ} \mathrm{C}$ for $1 \mathrm{~h}$, warmed to room temperature and stirred for 3 h. Upon warming, the slurry became a pale brown solution which turned red and finally yellow. The volatiles were removed under vacuum and the residue was taken up in deionized water (50 $\mathrm{mL}$ ). The aqueous mixture was acidified with dilute $\mathrm{HCl}$ to $\mathrm{pH} \sim 2$. The mixture was extracted with $\mathrm{CH}_{2} \mathrm{Cl}_{2}(3 \times 60 \mathrm{~mL})$. The extracts were combined, dried over $\mathrm{MgSO}_{4}$, and evaporated under vacuum to yield a pale yellow solid. The solid was washed with THF and $\mathrm{Et}_{2} \mathrm{O}$ to afford a white powder. The powder was dried under vacuum. Yield $3.03 \mathrm{~g}$ (70.3\% based on $p$-toluenesulfonic acid). ${ }^{1} \mathrm{H}$ NMR $\left(\mathrm{CD}_{2} \mathrm{Cl}_{2}\right): \delta 9.49\left(\mathrm{~d}, J_{\mathrm{PH}}=400,1 \mathrm{H}, \mathrm{P}-H\right), 8.14\left(\mathrm{dd}, J_{\mathrm{HH}}=6.5, J_{\mathrm{PH}}=5.5,1 \mathrm{H}\right.$, $\left.H^{3}-\mathrm{ArSO}_{3}\right), 7.77\left(\mathrm{~m}, 2 \mathrm{H}, H^{4}-\mathrm{Ph}\right), 7.66-7.58\left(\mathrm{~m}, 10 \mathrm{H}, \mathrm{H}^{4}-\mathrm{ArSO}_{3}, H^{2}-\mathrm{Ph}, H^{3}-\mathrm{Ph}\right), 7.07\left(\mathrm{~d}, J_{\mathrm{PH}}=\right.$ 15, $\left.1 \mathrm{H}, H^{6}-\mathrm{ArSO}_{3}\right), 2.33\left(\mathrm{~s}, 3 \mathrm{H}, \mathrm{CH}_{3} \mathrm{ArSO}_{3}\right) \cdot{ }^{13} \mathrm{C}\left\{{ }^{1} \mathrm{H}\right\} \mathrm{NMR}\left(\mathrm{CD}_{2} \mathrm{Cl}_{2}\right): \delta 151.0\left(\mathrm{~d}, J_{\mathrm{PC}}=8.2\right.$, $\left.C^{2}-\mathrm{ArSO}_{3}\right), 141.2\left(\mathrm{~d}, J_{\mathrm{PC}}=20, C^{5}-\mathrm{ArSO}_{3}\right), 136.6\left(\mathrm{~d}, J_{\mathrm{PC}}=2.8, C^{4}-\mathrm{ArSO}_{3}\right), 135.2\left(\mathrm{~d}, J_{\mathrm{PC}}=15\right.$, $\left.C^{6}-\mathrm{ArSO}_{3}\right), 135.1\left(\mathrm{~s}, C^{4}-\mathrm{Ph}\right), 134.2\left(\mathrm{~d}, J_{\mathrm{PC}}=11, C^{2}-\mathrm{Ph}\right), 130.5\left(\mathrm{~d}, J_{\mathrm{PC}}=13, C^{3}-\mathrm{Ph}\right), 129.2\left(\mathrm{~d}, J_{\mathrm{PC}}\right.$ $\left.=9.8, C^{5}-\mathrm{ArSO}_{3}\right), 119.2\left(\mathrm{~d}, J_{\mathrm{PC}}=90, C^{1}-\mathrm{ArSO}_{3}\right), 113.5\left(\mathrm{~d}, J_{\mathrm{PC}}=86, C^{1}-\mathrm{Ph}\right), 21.5\left(\mathrm{~s}, \mathrm{CH}_{3} \mathrm{ArSO}_{3}\right)$. ${ }^{31} \mathrm{P}\left\{{ }^{1} \mathrm{H}\right\}$ NMR $\left(\mathrm{CD}_{2} \mathrm{Cl}_{2}\right): \delta 4.07$ (br s).

[PO-H]Pd(Me)(py) (1c). A solution of $[\mathrm{PO}-\mathrm{H}] \mathrm{H} \quad(0.354 \mathrm{~g}, 1.00 \mathrm{mmol})$ and (TMEDA)PdMe $2(0.252 \mathrm{~g}, 1.00 \mathrm{mmol})$ in $\mathrm{CH}_{2} \mathrm{Cl}_{2}(15 \mathrm{~mL})$ was cooled to $-78^{\circ} \mathrm{C}$ and stirred for $20 \mathrm{~min}$. Pyridine $(0.41 \mathrm{~mL}, 5.0 \mathrm{mmol})$ was added dropwise over $2 \mathrm{~min}$. The mixture was stirred at $-78{ }^{\circ} \mathrm{C}$ for $30 \mathrm{~min}$, warmed to room temperature, and stirred for $45 \mathrm{~min}$. A pale yellow solution formed. The volatiles were removed under vacuum to afford a pale yellow solid. The solid was washed with hexanes and dried under vacuum to afford a white solid. This compound was further purified by recrystallization from $\mathrm{CH}_{2} \mathrm{Cl}_{2}$ and hexane. Yield $0.297 \mathrm{~g}, 51 \%$. ${ }^{1} \mathrm{H}$ NMR $\left(\mathrm{CD}_{2} \mathrm{Cl}_{2}\right): \delta 8.76\left(\mathrm{~m}, 2 \mathrm{H}, H^{2}\right.$-py), $8.03\left(\mathrm{dd}, J_{\mathrm{HH}}=6.2, J_{\mathrm{PH}}=4.4,1 \mathrm{H}, H^{3}-\mathrm{ArSO}_{3}\right), 7.90(\mathrm{~m}, 1 \mathrm{H}$, $H^{4}$-py), $7.63-7.58$ (m, 4H, $H^{3}$-py, $H^{4}$-Ph), 7.54-7.43 (m, 8H, $\left.H^{2}-\mathrm{Ph}, H^{3}-\mathrm{Ph}\right), 7.35$ (d, $J_{\mathrm{HH}}=8.0$, $\left.1 \mathrm{H}, H^{4}-\mathrm{ArSO}_{3}\right), 6.83\left(\mathrm{~d}, J_{\mathrm{PH}}=10,1 \mathrm{H}, H^{6}-\mathrm{ArSO}_{3}\right), 2.24\left(\mathrm{~s}, 3 \mathrm{H}, \mathrm{CH}_{3} \mathrm{ArSO}_{3}\right), 0.49\left(\mathrm{~d}, J_{\mathrm{PH}}=2.8\right.$, $\left.3 \mathrm{H}, \mathrm{Pd}-\mathrm{CH}_{3}\right) .{ }^{13} \mathrm{C}\left\{{ }^{1} \mathrm{H}\right\} \mathrm{NMR}\left(\mathrm{CD}_{2} \mathrm{Cl}_{2}\right): \delta 150.7$ (s, o-py), $147.2\left(\mathrm{~d}, J_{\mathrm{PC}}=14, C^{2}-\mathrm{ArSO}_{3}\right), 140.9(\mathrm{~d}$, 
$\left.J_{\mathrm{PC}}=7.0, C^{5}-\mathrm{ArSO}_{3}\right), 139.1\left(\mathrm{~s}, C^{4}-\mathrm{ArSO}_{3}\right), 135.8(\mathrm{~s}, p-\mathrm{py}), 134.8\left(\mathrm{~d}, J_{\mathrm{PC}}=12, C^{2}-\mathrm{Ph}\right), 132.2(\mathrm{~s}$, $m$-py), $131.5\left(\mathrm{~d}, J_{\mathrm{PC}}=6.2, C^{4}-\mathrm{Ph}\right), 130.5\left(\mathrm{~d}, J_{\mathrm{PC}}=55, C^{1}-\mathrm{Ph}\right), 129.1\left(\mathrm{~d}, J_{\mathrm{PC}}=11, C^{3}-\mathrm{Ph}\right), 128.7(\mathrm{~d}$, $\left.J_{\mathrm{PC}}=8.1, C^{3}-\mathrm{ArSO}_{3}\right), 128.5\left(\mathrm{~d}, J_{\mathrm{PC}}=44, C^{1}-\mathrm{ArSO}_{3}\right), 125.8\left(\mathrm{~s}, C^{6}-\mathrm{ArSO}_{3}\right), 21.6\left(\mathrm{~s}, \mathrm{CH}_{3} \mathrm{ArSO}_{3}\right)$, $0.82\left(\mathrm{~d}, J_{\mathrm{PC}}=2.0, \mathrm{Pd}-\mathrm{CH}_{3}\right) \cdot{ }^{31} \mathrm{P}\left\{{ }^{1} \mathrm{H}\right\}$ NMR $\left(\mathrm{CD}_{2} \mathrm{Cl}_{2}\right): \delta 28.4$ (s). Calcd for $\mathrm{C}_{25} \mathrm{H}_{24} \mathrm{NO}_{3} \mathrm{PSPd}: \mathrm{C}$, 54.01; H, 4.35; N, 2.52. Found: C, 53.84; H, 4.37; N, 2.68.

Standard procedure for Ethylene/VF copolymerization. Copolymerizations of ethylene and VF were performed in $300 \mathrm{~mL}$ stainless steel Parr autoclave equipped with a water cooling loop, thermocouple and magnetically coupled stirrer, and controlled by a Parr 4842 controller. In the glove box, the catalyst $(6 \mathrm{mg}, 10 \mu \mathrm{mol})$ was weighed into a glass autoclave liner. Toluene $(50 \mathrm{~mL})$ was added. The liner was placed in the autoclave, and the autoclave was assembled and brought out of the box. The autoclave was exposed to vacuum briefly, pressurized with VF to the desired pressure and ethylene was added until the total pressure reached 300 psi. The pressure was maintained at 300 psi by addition of ethylene on demand. The reactor was heated to the desired temperature $\left(80^{\circ} \mathrm{C}\right)$ and stirring $(170 \mathrm{rpm})$ was started. After $2 \mathrm{~h}$, the ethylene flow was terminated and the pressure was released into a well-ventilated fume hood. Caution: Vinyl fluoride is anticipated to be a human carcinogen. ${ }^{4}$ The mixture was cooled to room temperature and $\mathrm{MeOH}(100 \mathrm{~mL})$ was added. The polymer was collected by filtration, washed with $\mathrm{MeOH}(20 \mathrm{~mL})$, and dried under high vacuum overnight.

Representative homopolymerization and copolymerization results are summarized in Table S-1. Note that entry 3-5 are replicates to demonstrate the reproducibility of the polymerization reactions. 
Table S-1. Representative ethylene/VF polymerization results. ${ }^{a}$

\begin{tabular}{|l|c|c|c|c|c|c|c|c|c|c|c|}
\hline Exp \# & ww069 & ww064 & ww061 & ww062 & ww063 & ww065 & ww072 & ww070 & ww071 & ww091 & ww097 \\
\hline Entry & 1 & 2 & 3 & 4 & 5 & 6 & 7 & 8 & 9 & 10 & 11 \\
\hline Cat & $\mathbf{1 a}$ & $\mathbf{1 a}$ & $\mathbf{1 a}$ & $\mathbf{1 a}$ & $\mathbf{1 a}$ & $\mathbf{1 a}$ & $\mathbf{1 a}$ & $\mathbf{1 b}$ & $\mathbf{1 c}$ & $\mathbf{1 a}^{f}$ & AIBN $^{g}$ \\
\hline $\begin{array}{l}P_{\mathrm{VF}} \\
(\mathrm{psi})^{b}\end{array}$ & 0 & 40 & 80 & 80 & 80 & 160 & 240 & 80 & 80 & 80 & 80 \\
\hline $\begin{array}{l}P_{\mathrm{CH} 2 \mathrm{CH} 2} \\
(\mathrm{psi})^{b}\end{array}$ & 300 & 260 & 220 & 220 & 220 & 140 & 60 & 220 & 220 & 220 & 220 \\
\hline Yield $(\mathrm{g})^{b}$ & 5.93 & 0.77 & 0.48 & 0.47 & 0.44 & 0.17 & 0.10 & 0.22 & 0.41 & 0.53 & 0.02 \\
\hline $\mathrm{M}_{\mathrm{n}}\left(10^{3}\right)^{c}$ & 16.6 & 14.5 & 13.7 & 12.1 & 12.4 & 8.6 & 6.8 & 6.2 & 4.5 & 13.2 & 11.2 \\
\hline $\mathrm{M}_{\mathrm{w}}\left(10^{3}\right)^{c}$ & 56.3 & 43.6 & 38.8 & 36.1 & 35.4 & 23.8 & 17.7 & 17.0 & 11.2 & 38.5 & 19.0 \\
\hline $\mathrm{M}_{\mathrm{w}} / \mathrm{M}_{\mathrm{n}}{ }^{c}$ & 3.4 & 3.0 & 2.8 & 3.0 & 2.9 & 2.7 & 2.6 & 2.7 & 2.5 & 2.9 & 1.7 \\
\hline $\mathrm{Me}_{1} / 0^{3} \mathrm{C}$ & 0.3 & 1.3 & 1.2 & 1.0 & 0.9 & 1.1 & 2.4 & 2.7 & 4.7 & 1.0 & 70 \\
\hline $\begin{array}{l}\mathrm{VF} \text { Incorp } \\
(\mathrm{mol} \%)^{d}\end{array}$ & NA & 0.09 & 0.16 & 0.13 & 0.17 & 0.37 & 0.45 & 0.15 & 0.14 & 0.15 & 8 \\
\hline $\begin{array}{l}\text { VF per } \\
\text { chain }\end{array}$ & NA & 0.9 & 1.1 & 0.6 & 1.2 & 2.2 & 1.3 & 0.4 & 0.4 & 2.1 & NA \\
\hline $\mathrm{T}_{\mathrm{m}}\left({ }^{\circ} \mathrm{C}\right)^{e}$ & 133.6 & 132.6 & 132.2 & 132.6 & 132.6 & 131.7 & 130.7 & 130.2 & 129.6 & 131.7 & 116.5 \\
\hline
\end{tabular}

${ }^{a}$ Conditions: toluene, $50 \mathrm{~mL}$, [cat] $=0.2 \mathrm{mM}, 80{ }^{\circ} \mathrm{C}, 2 \mathrm{~h}$, total pressure $300 \mathrm{psi}^{b}{ }^{b}$ The reactor was charged with the given pressure of VF at $25{ }^{\circ} \mathrm{C}$, pressurized with ethylene (on demand) to achieve a total pressure of $300 \mathrm{psi}$, and then heated to $80{ }^{\circ} \mathrm{C} .{ }^{c} \mathrm{GPC} .{ }^{d} \mathrm{~mol} \% \mathrm{VF}$ incorporation in copolymer determined by NMR. ${ }^{e}$ DSC. ${ }^{f}$ contains galvinoxyl $(21 \mathrm{mg}, 0.05 \mathrm{mmol}, 5$ equiv. vs. Pd). ${ }^{g} 5 \mathrm{mg}(0.03 \mathrm{mmol})$ AIBN was used.

Attempted homopolymerization of VF by 1a. In the glove box, 1a $(6 \mathrm{mg}, 10 \mu \mathrm{mol})$ was weighed into a glass autoclave liner. Toluene $(50 \mathrm{~mL})$ was added. The liner was placed in the autoclave, and the autoclave was assembled and brought out of the box. The autoclave was pressurized with VF to $160 \mathrm{psi}$, heated to $80^{\circ} \mathrm{C}$ and stirring at $170 \mathrm{rpm}$ was initiated. After $2 \mathrm{~h}$, the reactor was vented and the volatiles were removed under vacuum. Only $\sim 3.8 \mathrm{mg}$ residue was obtained. ${ }^{1} \mathrm{H}$ and ${ }^{19} \mathrm{~F}\left\{{ }^{1} \mathrm{H}\right\}$ NMR spectra showed that no poly(vinyl fluoride) had formed. The ${ }^{31} \mathrm{P}\left\{{ }^{1} \mathrm{H}\right\}$ NMR spectrum contained signals at $\delta 16.0,11.8$ and -2.1 , suggesting that this material contains catalyst decomposition products.

Removal of volatile compounds from copolymer. A flask was charged with copolymer (28 mg, Table S-1, entry 3) and toluene $(10 \mathrm{~mL})$. The mixture was heated with a heat gun until all of the polymer dissolved. The flask was heated in an oil bath $\left(140^{\circ} \mathrm{C}\right)$ to evaporate all volatiles. This procedure was repeated twice. The flask was then exposed to high vacuum 
overnight. The ${ }^{1} \mathrm{H}$ and ${ }^{19} \mathrm{~F}$ spectra of the copolymer were unchanged by this procedure.

Recrystallization of copolymer from $\mathbf{C H C l}_{\mathbf{2}} \mathbf{C H C l}_{2}$. A test tube was charged with copolymer (25 mg, Table 1, entry 3 ) and $\mathrm{CHCl}_{2} \mathrm{CHCl}_{2}(5 \mathrm{~mL})$. The mixture was heated with a heat gun until all of the polymer dissolved. The solution was allowed to cool to room temperature and kept still in a test tube rack for 3 days. The copolymer precipitated and floated to the top of solvent. The $\mathrm{CHCl}_{2} \mathrm{CHCl}_{2}$ was removed carefully using a syringe. This procedure was repeated. The $\mathrm{CHCl}_{2} \mathrm{CHCl}_{2}$ fractions were combined, passed through a pad of celite and evaporated, leaving a trace amount of residue $(1.2 \mathrm{mg}) .{ }^{1} \mathrm{H}$ and ${ }^{19} \mathrm{~F}\left\{{ }^{1} \mathrm{H}\right\}$ NMR analysis of the residue (in $\mathrm{CDCl}_{2} \mathrm{CDCl}_{2}$ ) showed no signals for the copolymer. The purified copolymer was dried under vacuum ( 20 mg solid was obtained). The ${ }^{1} \mathrm{H}$ and ${ }^{19} \mathrm{~F}\left\{{ }^{1} \mathrm{H}\right\}$ NMR spectra were unchanged by this procedure.

\section{Copolymerization of ethylene and VF by 1a in the presence of galvinoxyl (Table S-1,}

entry 10). The standard copolymerization procedure was used except galvinoxyl (21 mg, 50 $\mu$ mol, 5 equiv. vs. Pd) was also added. After the polymerization period, the mixture was cooled to room temperature and $100 \mathrm{~mL} \mathrm{MeOH}$ was added. The polymer was collected by filtration, washed with Toluene $(25 \mathrm{~mL})$ and $\mathrm{MeOH}(20 \mathrm{~mL})$, and dried under high vacuum overnight. Yield: $530 \mathrm{mg}$. The ${ }^{1} \mathrm{H}$ and ${ }^{19} \mathrm{~F}\left\{{ }^{1} \mathrm{H}\right\}$ NMR spectra were similar to the spectra of copolymer obtained by 1a in the absence of galvinoxyl (Table S-1, entry 3-5). The presence of unreacted galvinoxyl was confirmed by GC/MS as well as UV/Vis (absorbance at $428 \mathrm{~nm}$ ). ${ }^{5,6}$ An estimate of amount of galvinoxyl (19.7 mg) was obtained from comparison of the galvinoxyl integral to that of added internal standard - 1,3,5- trisisopropylbenzene. Similar results were obtained on repeated runs.

Copolymerization of ethylene and VF by AIBN (Table S-1, entry 11). The standard copolymerization procedure was used. After the polymerization period, the volatiles were removed under vacuum. The remaining solid (24 mg) was analyzed without further purification.

Attempted copolymerization of ethylene and VF by AIBN in the presence of galvinoxyl. The copolymerization procedure in Table S-1, entry 11 was followed except galvinoxyl $(64 \mathrm{mg}, 150 \mu \mathrm{mol})$ were also added. After the polymerization period, the volatiles were removed under vacuum. The remaining solid was analyzed without further purification. The yield was estimated by substraction of the weight of galvinoxyl (64 mg) from the total solid product remaining (Yield: $<5 \mathrm{mg}$ ). ${ }^{1} \mathrm{H}$ and ${ }^{19} \mathrm{~F}\left\{{ }^{1} \mathrm{H}\right\}$ NMR analysis of the residue (in 1,2-DCB- $d_{4}$ ) 
showed no signals for the copolymer. The presence of unreacted galvinoxyl was confirmed by GC/MS and UV/Vis (absorbance at $428 \mathrm{~nm}$ ).

Recrystallization of 1a-produced copolymer from 1,2-dichlorobenzene. A test tube was charged with copolymer (29 mg, Table S-1, entry 3) and 1,2-dichlorobenzene (5 mL). The mixture was heated with a heat gun until all of the polymer dissolved. The solution was allowed to cool to room temperature and kept still in a test tube rack for 2 days. The copolymer precipitated and floated to the top of solvent. The 1,2-dichlorobenzene solution was removed carefully using a syringe. This procedure was repeated. The 1,2-dichlorobenzene fractions were

combined, passed through a pad of celite and evaporated. ${ }^{1} \mathrm{H}$ and ${ }^{19} \mathrm{~F}\left\{{ }^{1} \mathrm{H}\right\}$ NMR analysis of the residue showed no signals for the copolymer.

\section{Recrystallization of a mixture of 1a-produced copolymer and AIBN-produced} copolymer. A test tube was charged with 1a-produced copolymer (24 mg, Table 1, entry 3), AIBN produced copolymer (20 mg, Table S-1, entry 11) and 1,2-dichlorobenzene (5 mL). The mixture was heated with a heat gun until all of the polymer dissolved. The solution was allowed to cool to room temperature and kept still in a test tube rack for 2 days. The copolymer precipitated and floated to the top of solvent. The 1,2-dichlorobenzene solution was removed carefully using a syringe. This procedure was repeated. The 1,2-dichlorobenzene fractions were combined, passed through a pad of celite and evaporated. ${ }^{1} \mathrm{H}$ and ${ }^{19} \mathrm{~F}\left\{{ }^{1} \mathrm{H}\right\}$ NMR analysis of the residue showed signals for the copolymer produced by AIBN. 


\section{Representative NMR spectra of copolymers.}

\section{1,2-DCB}

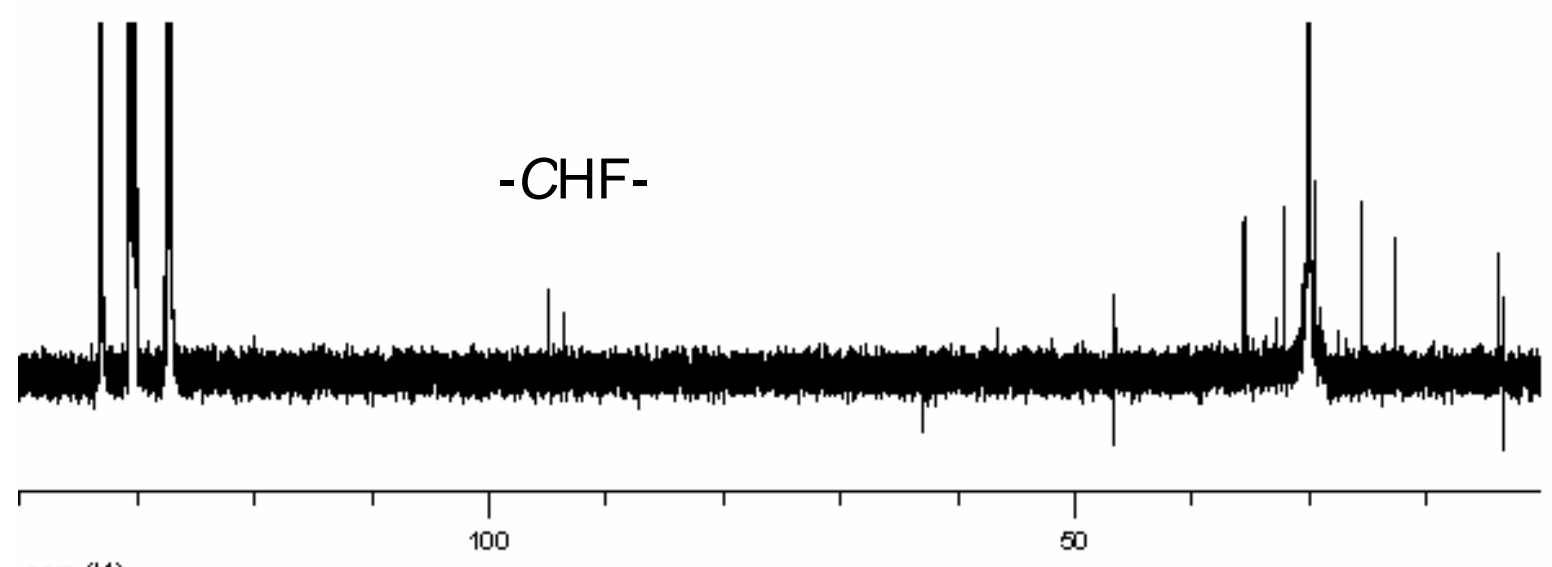

ppm (t1)

Figure S-1a. ${ }^{13} \mathrm{C}\left\{{ }^{1} \mathrm{H}\right\}$ NMR $\left(1,2-\mathrm{DCB}-d_{4}, 110{ }^{\circ} \mathrm{C}\right)$ of ethylene/VF copolymer (Table S-1, entry $10)$.
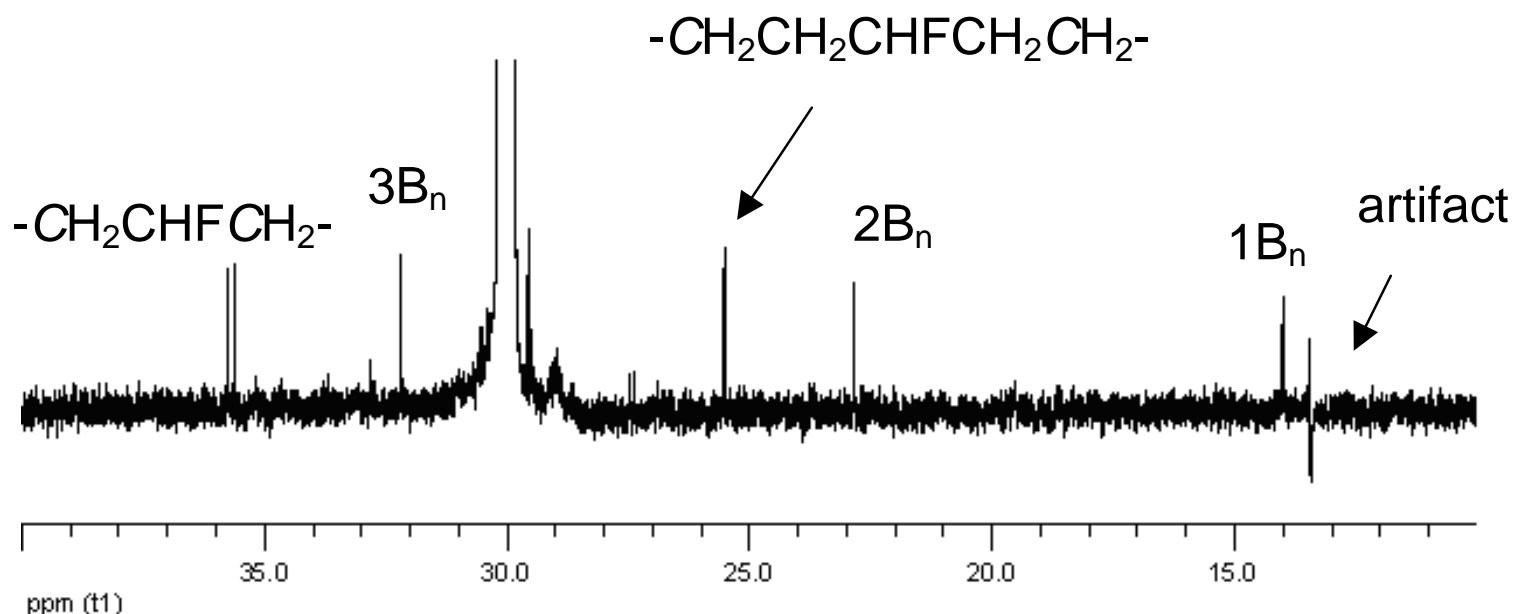

Figure S-1b. ${ }^{13} \mathrm{C}\left\{{ }^{1} \mathrm{H}\right\}$ NMR $\left(1,2-\mathrm{DCB}-d_{4}, 110{ }^{\circ} \mathrm{C}\right)$ of ethylene/VF copolymer (Table S-1, entry 10). Expansion of the $\delta 40$ to 10 region. 

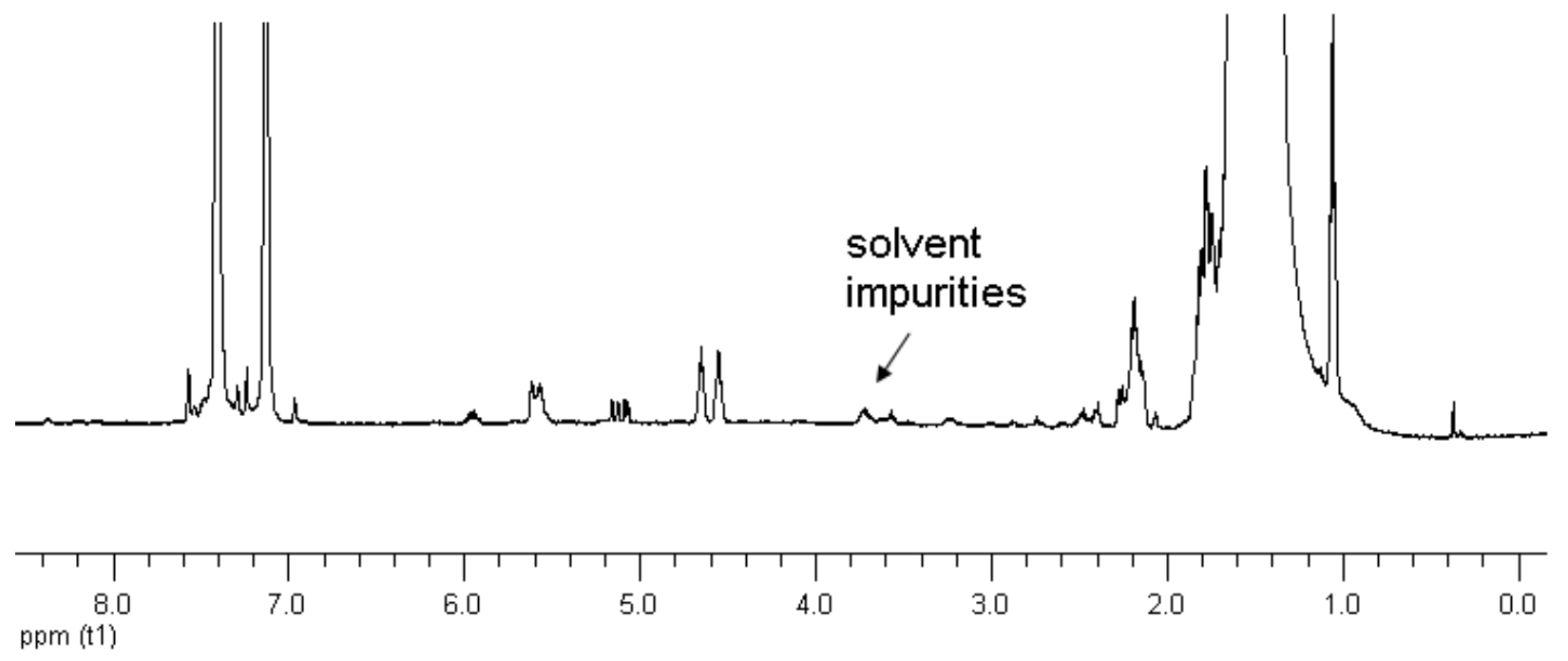

Figure S-1c. ${ }^{1} \mathrm{H}$ NMR $\left(1,2-\mathrm{DCB}-d_{4}, 110{ }^{\circ} \mathrm{C}\right)$ of ethylene/VF copolymer (Table S-1, entry 10).

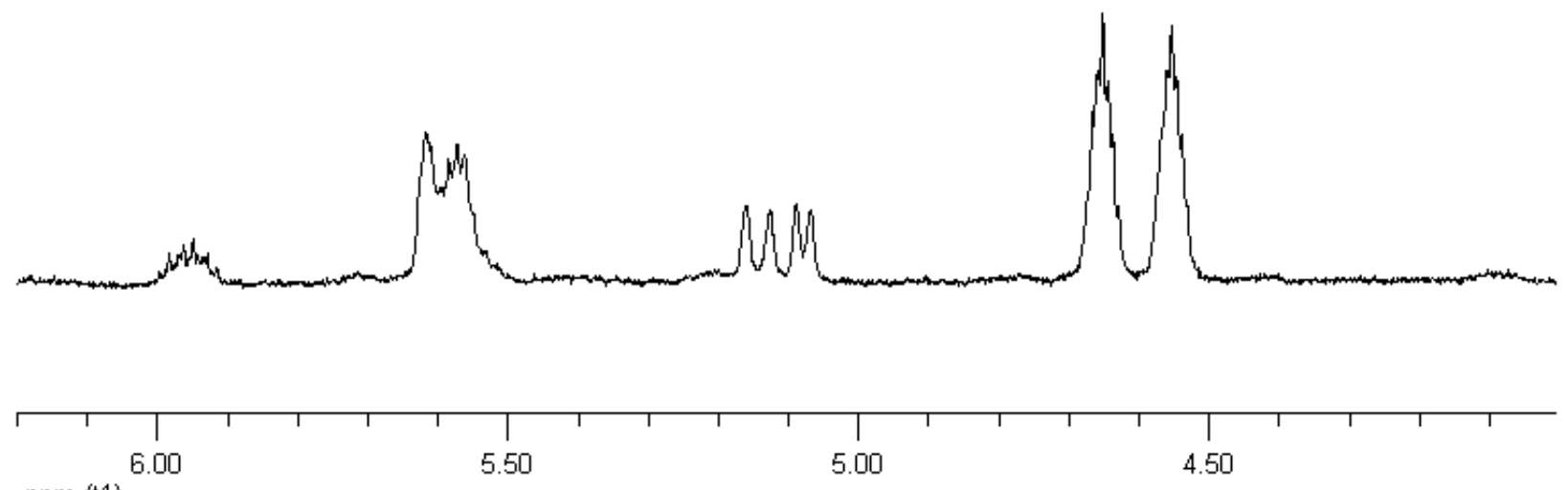
ppm (t1)

Figure S-1d. ${ }^{1} \mathrm{H}$ NMR $\left(1,2-\mathrm{DCB}-d_{4}, 110^{\circ} \mathrm{C}\right)$ of ethylene/VF copolymer (Table S-1, entry 10). Expansion of the $\delta 6.2$ to 4.0 region. 

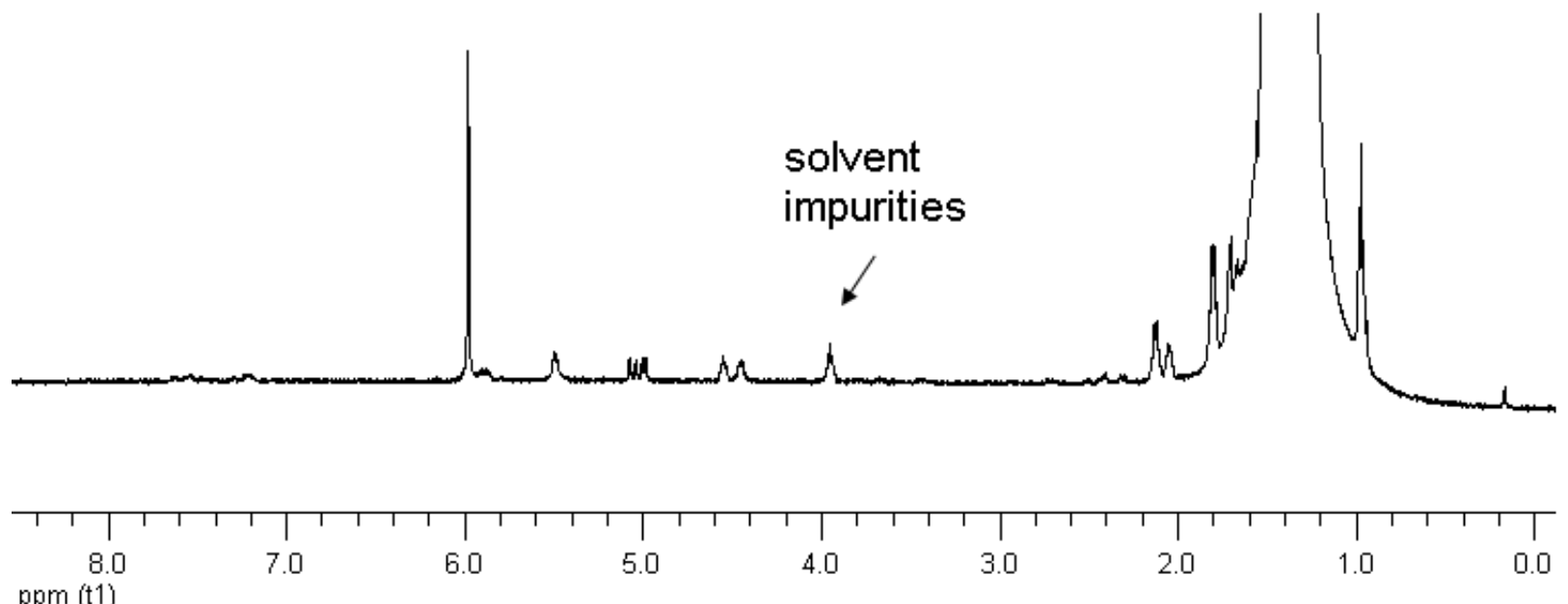

Figure S-2a. ${ }^{1} \mathrm{H} \mathrm{NMR}\left(\mathrm{CDCl}_{2} \mathrm{CDCl}_{2}, 120{ }^{\circ} \mathrm{C}\right)$ of ethylene/VF copolymer (Table S-1, entry 2$)$.

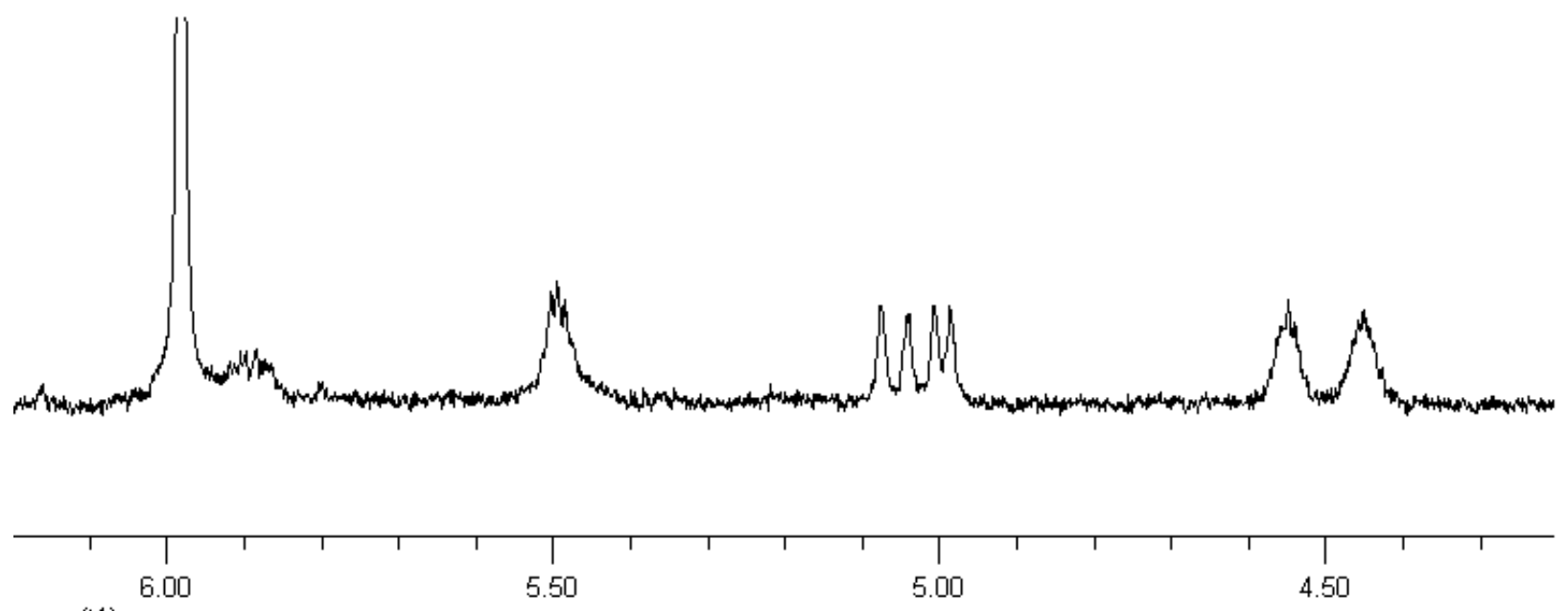
ppm (t1)

Figure S-2b. ${ }^{1} \mathrm{H} \mathrm{NMR}\left(\mathrm{CDCl}_{2} \mathrm{CDCl}_{2}, 120^{\circ} \mathrm{C}\right)$ of ethylene/VF copolymer (Table S-1, entry 2$)$. Expansion of the $\delta 6.2$ to 4.2 region. 

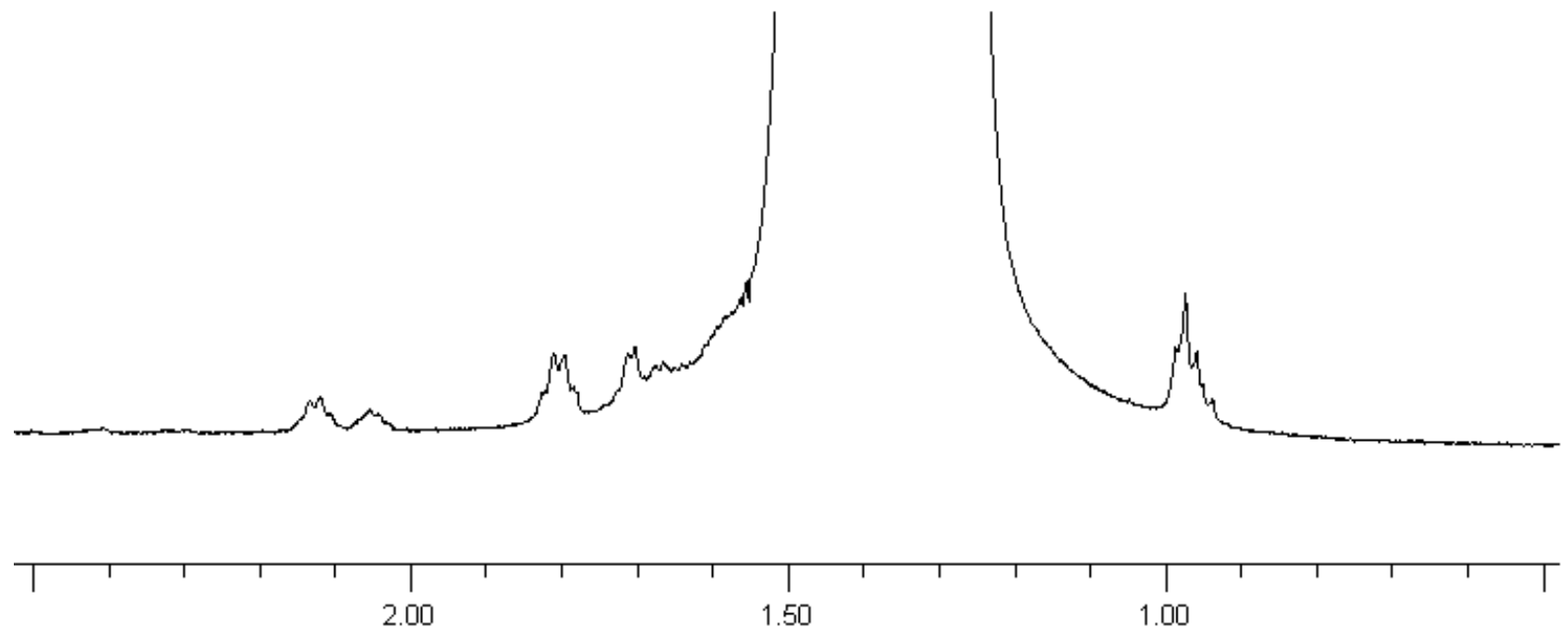

ppm (t1)

Figure S-2c. ${ }^{1} \mathrm{H}$ NMR $\left(\mathrm{CDCl}_{2} \mathrm{CDCl}_{2}, 120^{\circ} \mathrm{C}\right)$ of ethylene/VF copolymer (Table S-1, entry 2). Expansion of the $\delta 2.5$ to 0.5 region.

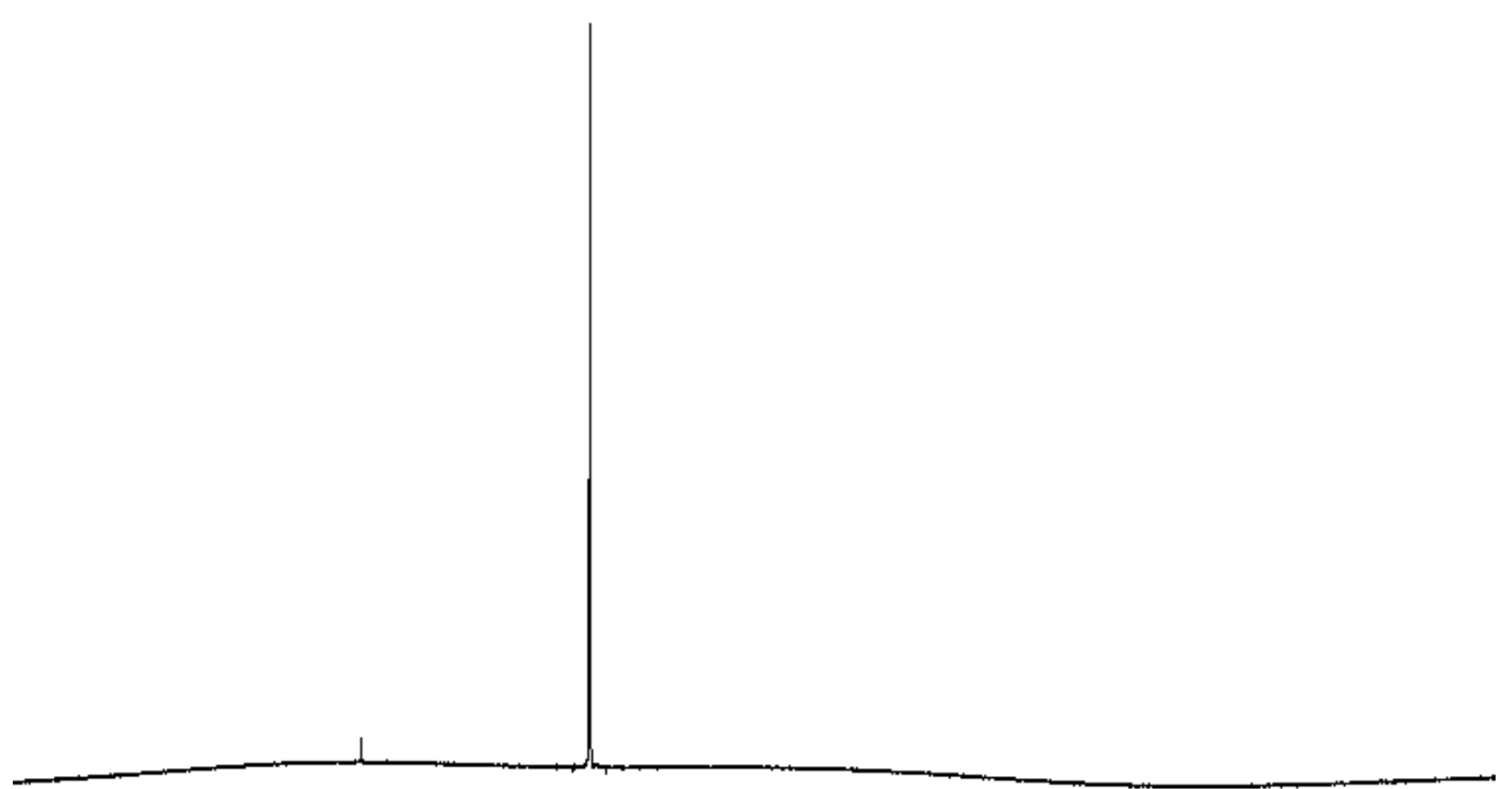

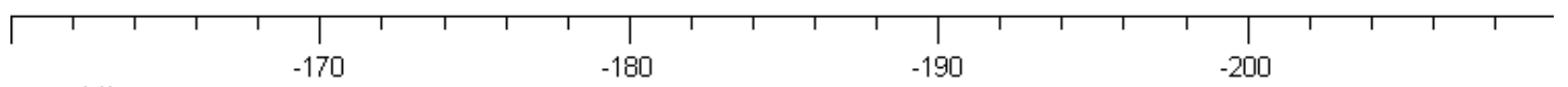

ppm (t1)

Figure S-3. ${ }^{19} \mathrm{~F}$ NMR $\left(1,2\right.$-DCB- $\left.d_{4}, 110{ }^{\circ} \mathrm{C}\right)$ of ethylene/VF copolymer (Table S-1, entry 3 ). Expansion of the $\delta-160$ to -200 region. 

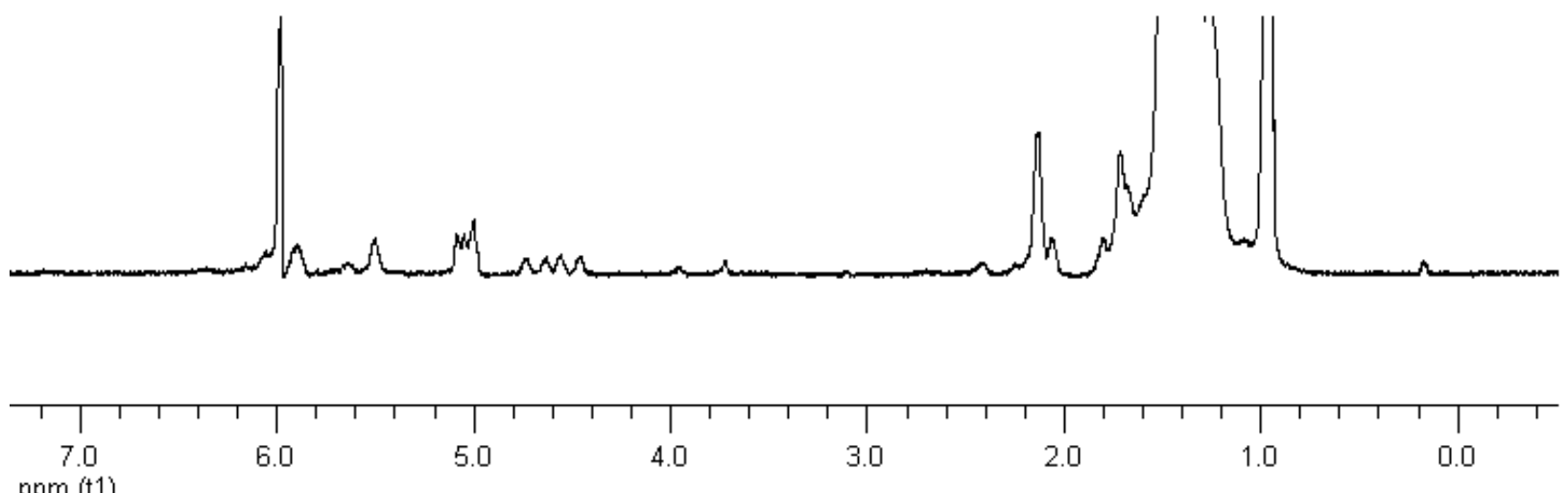

ppm (t1)

Figure S-4a. ${ }^{1} \mathrm{H}$ NMR $\left(\mathrm{CDCl}_{2} \mathrm{CDCl}_{2}, 120^{\circ} \mathrm{C}\right)$ of ethylene/VF copolymer clearly showing $-\mathrm{CH}_{2} \mathrm{CHFMe}$ chain end. This copolymer was produced by $1 \mathbf{a}$ from a mixture of $80 \mathrm{psi} \mathrm{VF}$ and 120 psi ethylene at $100{ }^{\circ} \mathrm{C}$.
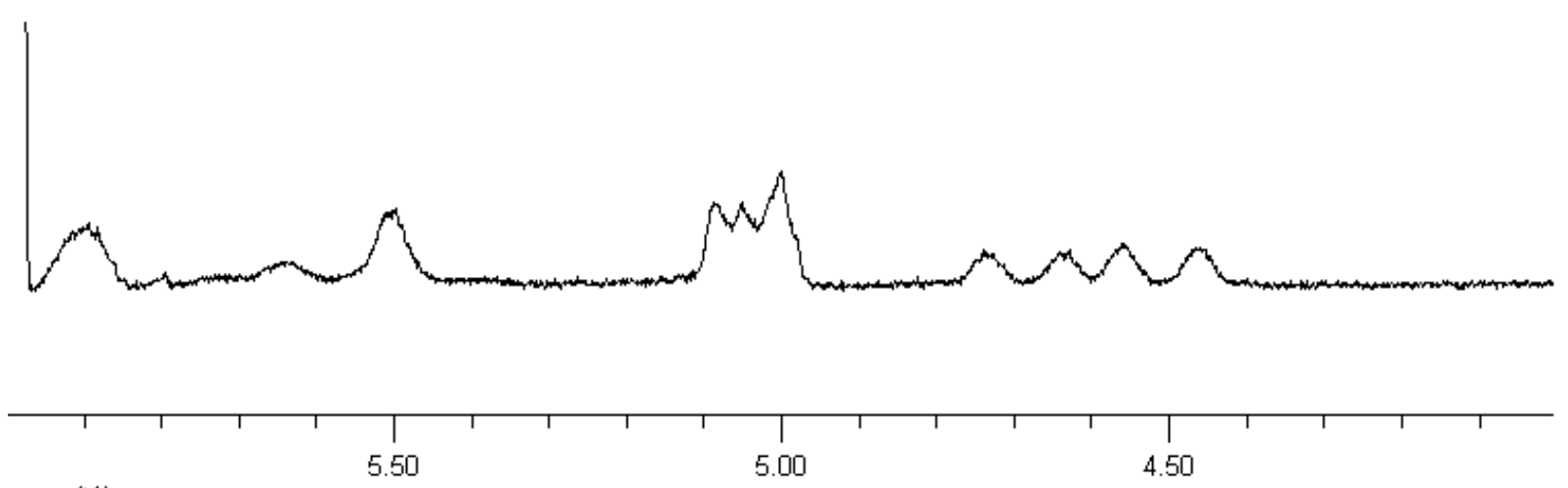

ppm (t1)

Figure S-4b. ${ }^{1} \mathrm{H}$ NMR $\left(\mathrm{CDCl}_{2} \mathrm{CDCl}_{2}, 120^{\circ} \mathrm{C}\right)$ of ethylene/VF copolymer clearly showing $-\mathrm{CH}_{2} \mathrm{CHFMe}$ chain end. Expansion of the $\delta 6.0$ to 4.0 region.

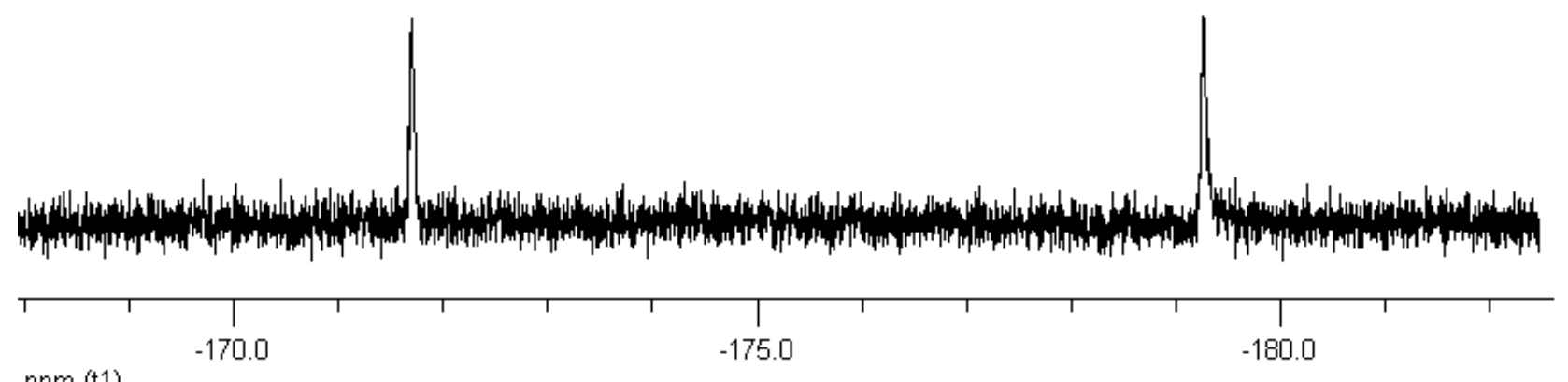

ppm (t1)

Figure S-4c. ${ }^{19} \mathrm{~F}$ NMR $\left(\mathrm{CDCl}_{2} \mathrm{CDCl}_{2}, 120{ }^{\circ} \mathrm{C}\right)$ of ethylene/VF copolymer clearly showing $-\mathrm{CH}_{2} \mathrm{CHFMe}$ chain end. Expansion of the $\delta-168.0$ to -182.5 region. 

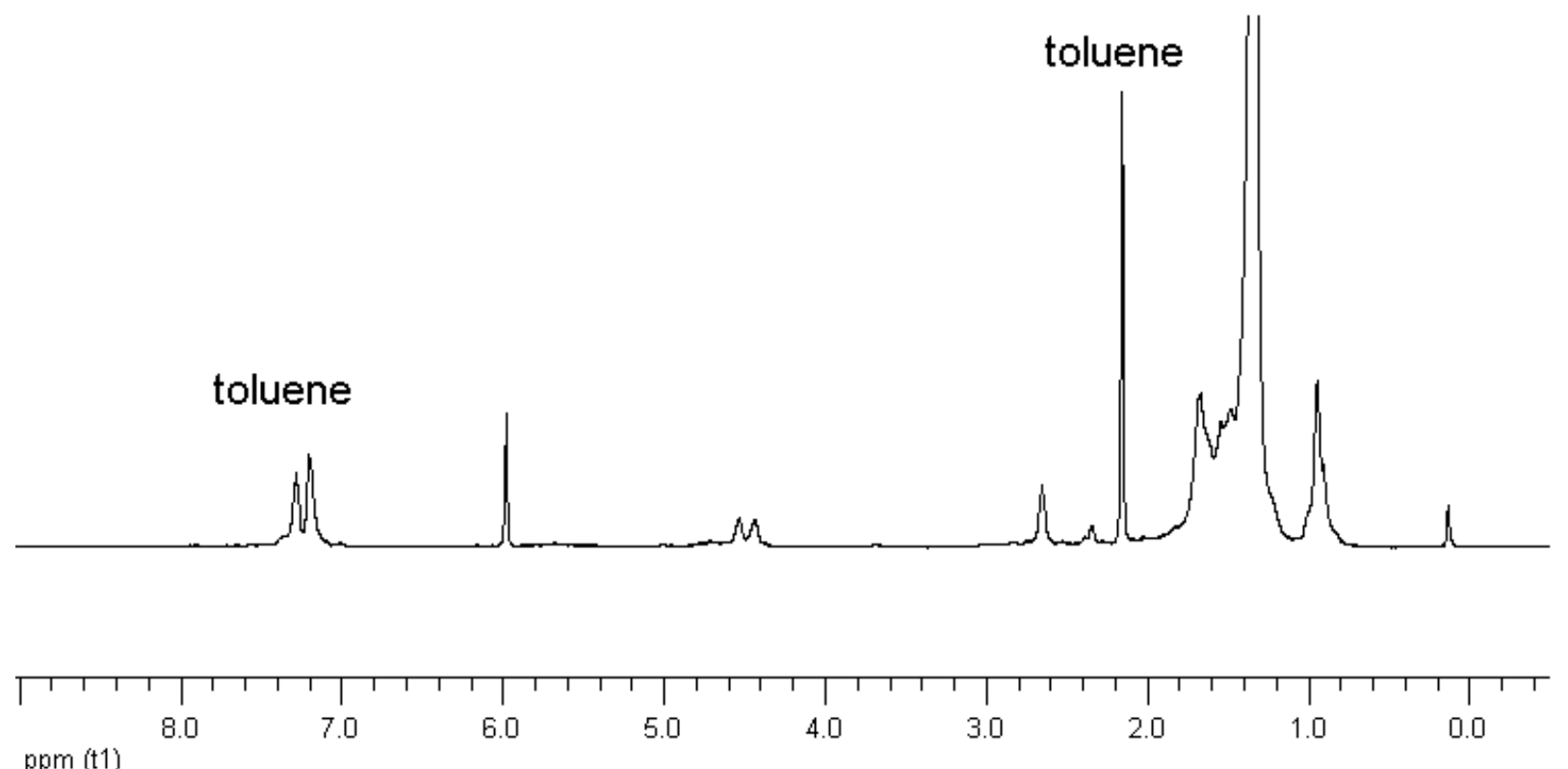

Figure S-5a. ${ }^{1} \mathrm{H} \mathrm{NMR}\left(\mathrm{CDCl}_{2} \mathrm{CDCl}_{2}, 120^{\circ} \mathrm{C}\right)$ ethylene/VF copolymer made by AIBN (Table S-1, entry 11).

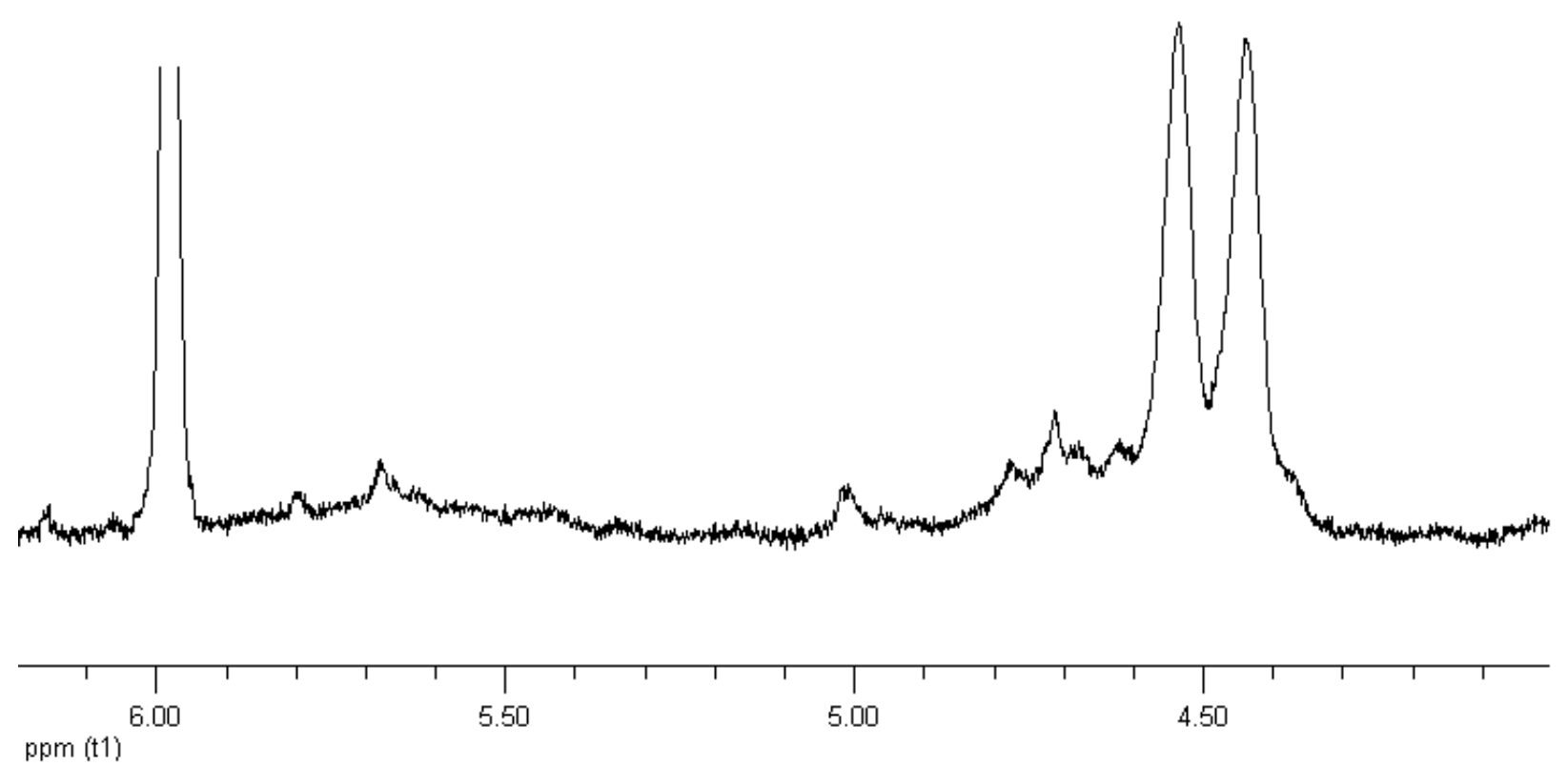

Figure S-5b. ${ }^{1} \mathrm{H}$ NMR $\left(\mathrm{CDCl}_{2} \mathrm{CDCl}_{2}, 120{ }^{\circ} \mathrm{C}\right)$ ethylene/VF copolymer made by AIBN (Table $\mathrm{S}-1$, entry 11). Expansion of the $\delta 6.2$ to 4.0 region. 


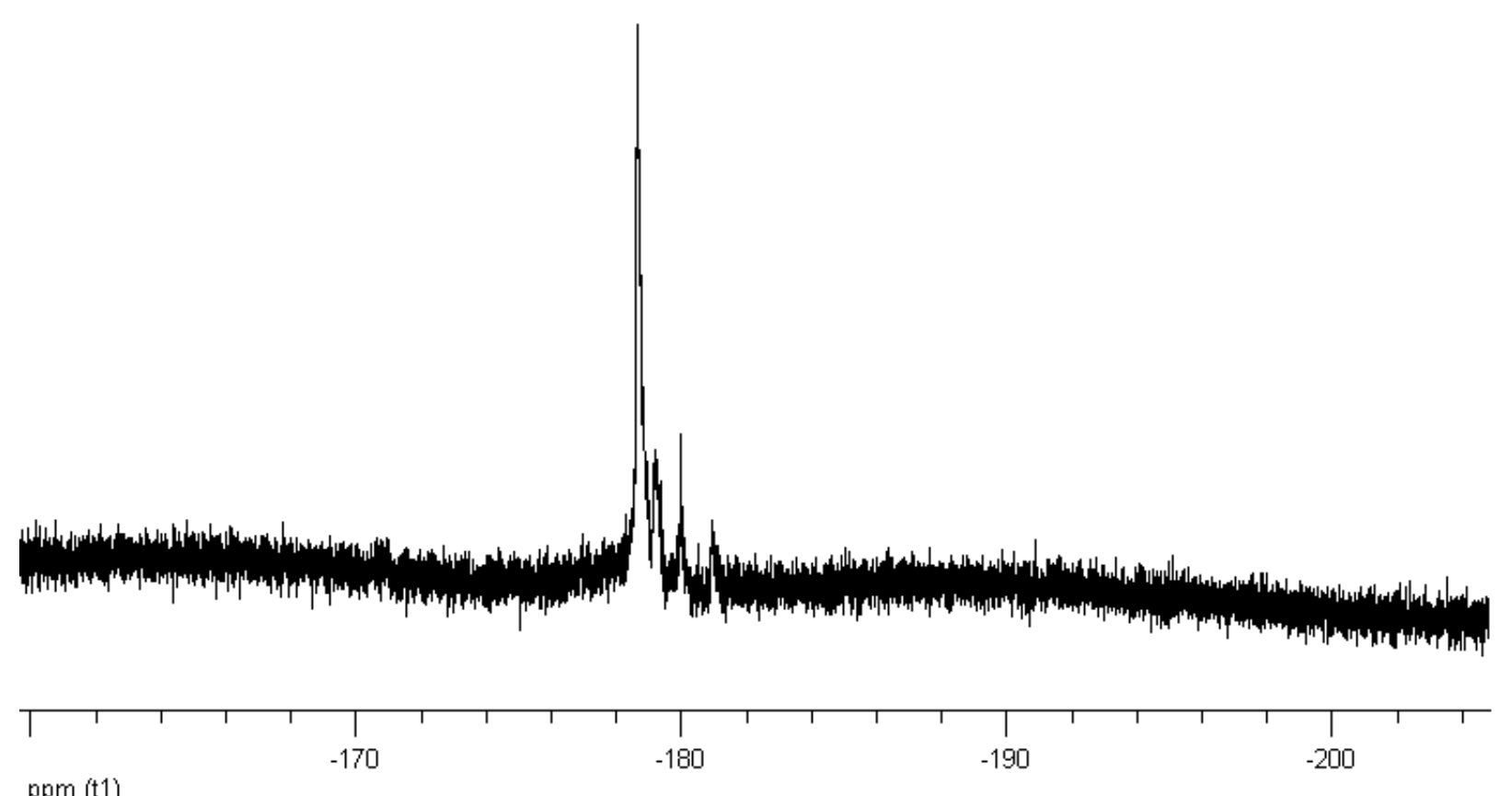

ppm (t1)

Figure S-5c. ${ }^{19} \mathrm{~F}\left\{{ }^{1} \mathrm{H}\right\}$ NMR $\left(\mathrm{CDCl}_{2} \mathrm{CDCl}_{2}, 120{ }^{\circ} \mathrm{C}\right)$ ethylene/VF copolymer made by AIBN (Table S-1, entry 11). Expansion of the $\delta-160$ to -204 region. 


\section{References}

1 (a) Luo, S.; Vela, J.; Lief, G. R.; Jordan, R. F. J. Am. Chem. Soc. 2006, 129, 8946. (b) Vela, J.; Lief, G. R.; Shen, Z.; Jordan, R. F. manuscript submitted.

${ }^{2}$ De Graaf, W.; Boersma, J.; Smeets, W. J. J.; Spek, A. L.; van Koten, G.. Organometallics 1989, 8, 2907.

${ }^{3}$ Grinshpun, V.; Rudin, A. Makromol. Chem., Rapid Commun. 1985, 6, 219.

${ }^{4} \mathrm{VF}$ is "reasonably anticipated to be a human carcinogen" according to the Report on Carcinogens, Tenth Ed., 2002, which is available on the Internet and can be accessed from the Environmental Health Perspectives website at: http://www.ehponline.org or from the NTP website at: http://ntp.niehs.nih.gov/ntp.

${ }^{5}$ Nakanishi, I.; Kawashima, T.; Ohkubo, K.; Kanazawa, H.; Inami, K.; Mochizuki, M.; Fukuhara, K.; Okuda, H.; Ozawa, T.; Itoh, S.; Fukuzumi, S.; Ikota, N. Org. Biomol. Chem. 2005, 3, 626.

${ }^{6}$ Decomposition products of galvinoxyl were also detected by GC/MS. Autooxidation of galvinoxyl by molecular oxygen has been previously reported. See for example: Dubinskii, V. Z.; Belyakov, V. A.; Roginskii, V. A.; Miller, V. B. Russ. Chem. Bull. 1975, 24, 44. 